\title{
Use of a lytic bacteriophage to control Salmonella Enteritidis in retail food
}

\begin{abstract}
A Salmonella Enteritidis lytic bacteriophage designated as SE07 was isolated from retail meat samples. Electron micrograph revealed that phage SE07 belonged to family Podoviridae. Phage SE07 was relatively stable at the temperature ranging from 28 to $65{ }^{\circ} \mathrm{C}$. Furthermore, it exhibited remarkable $\mathrm{pH}$ stability (between $\mathrm{pH} 4.0 \mathrm{I} 11.0$ ). The effectiveness of phage SE07 was determined in different food matrices (fruit juice, fresh eggs, beef and chicken meat) experimentally contaminated with S. Enteritidis. A significant reduction of S. Enteritidis population (about 2 log cycles) was obtained in fruit juice and fresh eggs after incubation at $4{ }^{\circ} \mathrm{C}$ for $48 \mathrm{~h}$. Furthermore, within the same period, bacterial population was reduced by 2.1 and $2.0 \mathrm{log}$ cycles on the bacteriophage treated beef and chicken meat samples, respectively. In this study, the obtained data suggested that phage SE07 might have potential uses against Salmonella food-borne infections.
\end{abstract}

Keyword: Salmonella Enteritidis; Isolation; Bacteriophage; Bio-control; Food 